\title{
A DUNA TÉRSÉG MINT FEJLESZTÉSI NAGYTÉRSÉG
}

\author{
(The Danube Region as a Macro-development Region)
}

\author{
HARDI TAMÁS
}

Kulcsszavak:

Duna Duna stratégia transznacionális régió folyóvölgyi tervezés Közép-Európa Délkelet-Európa

Az Európai Unió 2009-ben egy új fejlesztési nagyrégiót jelölt ki, a Duna térséget. Erre a térségre 2010-ben egy fejlesztési stratégiát készített, amely a részt vevö államok közremüködésével született meg. Tanulmányunk ennek a nagyrégiónak a belsö problémáit vizsgálja, abból kiindulva, hogy alkalmas-e ez a hatalmas, rendkivül heterogén és számos geopolitikai-etnikai problémával terhelt térség egy valódi, intenzív közös fejlödési pályát együttesen megvalósítani, illetve, ha a jelenlegi lehatárolást túlzónak tartjuk, milyen kiterjedésü az a földrajzi keret, ahol az intenzív együttmüködés megvalósulhat. Úgy látjuk, hogy a térség Európa egyik legváltozatosabb, de legproblematikusabb régiója is, ahol a nagytérségi együttmüködés elsősorban a politikai közeledést szolgálhatja. Az intenzív gazdasági-fejlesztési együttmüködéshez olyan közös érdekeltségeket kell megtalálni, amelyek felülírják a geopolitikai ellentéteket. Ennek földrajzi tereként a szükebb értelemben vett Duna-völgyet látjuk alkalmasnak. A két fejlesztési tér természetesen nem áll egymással szemben, azok alkalmazása kombinálható, söt, egymást erösítve kiegészítö szerepük lehet.

\section{A Duna stratégia területe}

Az utóbbi időben felerősödött az érdeklődés a Duna és a Duna térség mint fejlesztési együttműködési tér irányába. A néha kissé romantikusan értelmezett „dunaiság” mögé több kezdeményezés, dunai területeket tömörítő szervezet és program is felsorakozott. Az Európai Unió 2009-ben kezdeményezte egy Duna stratégia elkészítését, amely egy általános fejlesztési dokumentum. A stratégia által lefedett fejlesztési tér hatalmas, 1081964 km² kiterjedésü, s 116 millió lakost számlál. A programtér lényegében a Duna vízgyüjtőjére épül (1. ábra), de nagyobb kiterjedésủ annál, ugyanakkor gyenge intézményi és finanszírozási háttérrel rendelkezik. Ilyen formában a stratégia által lehatárolt teret csak reménybeli fejlesztési térként vehetjük számításba, a jelenlegi helyzet alapján inkább úgy fogalmazhatjuk meg, mint egy uniós ajánlást, amely az érintett országok politikai együttmüködését szorgalmazza, s annak megvalósítását némi uniós ráhatással ugyan, de belső ügynek tekinti. 


\section{1. ÁBRA}

A Duna stratégia területe és a vízgyüjtö viszonya, a vízgyüjtöben érintett államok (Relation of the Territory of the Danube Strategy and the Water Catchment Area of the River, and States Involved in the Water Catchment Area)

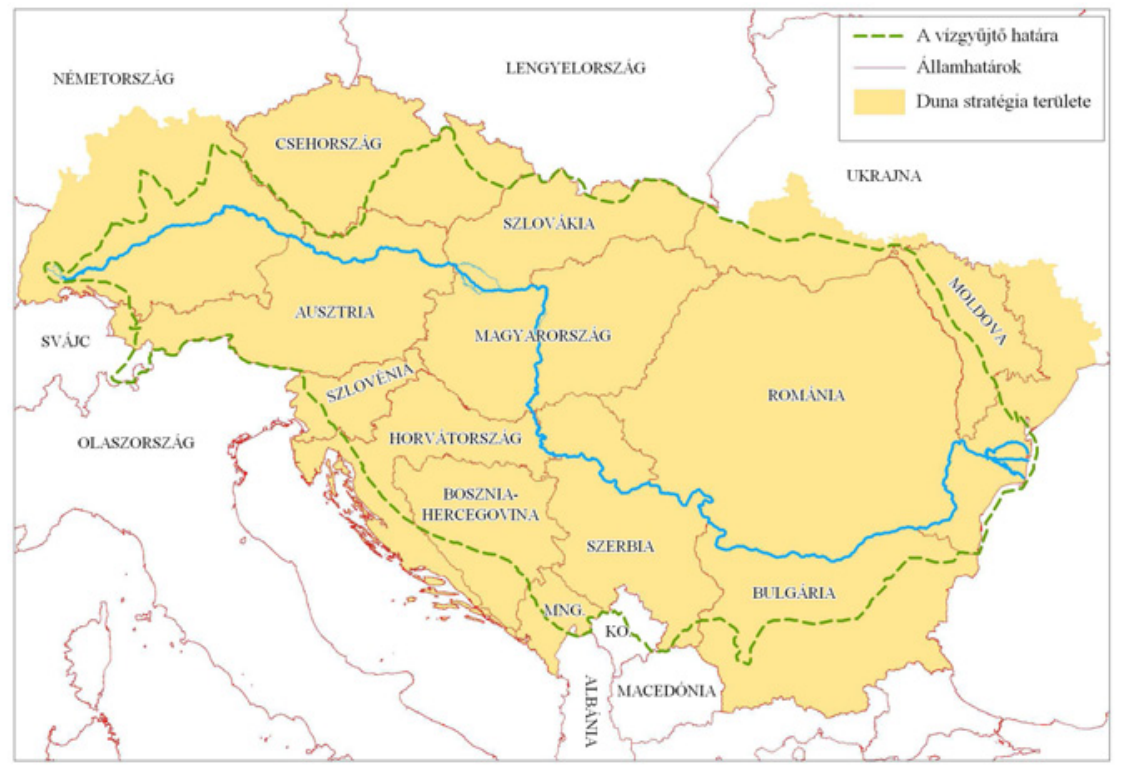

Jelmagyarázat: $\mathrm{MNG}=$ Montenegró; $\mathrm{KO}=$ Koszovó

Forrás: Saját szerkesztés.

A kezdeményezés mindazonáltal nagy port vert fel, elsősorban (és eddig) a diplomáciai események, a megtartott csúcstalálkozók miatt, s ismét előtérbe állította a Duna menti országok és népek együttmüködését, integrációját. Látható volt a hírekből, a különböző tárgyalások hozzászólásaiból, hogy a különböző szereplők fontosnak és lehetségesnek tartják a dunai együttműködést, kitapintható egyfajta lelkesedés, romantikus viszonyulás a Duna kérdéséhez. Lehet, hogy egy ilyen szimbólum mentén, s a gazdasági fejlödés ígéretével közeledhetnek egymáshoz politikailag széttagolt térségünk szereplői.

Az EU több hasonló nagytérség számára készíttetett az elmúlt években fejlesztési koncepciót. A Duna stratégia mellett ilyen anyag készült a Balti-tenger térségére, az Euro-Mediterraneumra, az Északi-tenger-Csatorna nagytérségre is. Vélhető, hogy ezekkel a nagyterekkel az unió célja, hogy fejlesztésekkel felülírja a közösségen belüli geopolitikai erőtereket, hozzájáruljon a dezintegráció megállításához, s a szembenálló nemzeti egységek helyett belső, szupranacionális fejlődési tereket hozzon létre. Ezek a terek valamely földrajzi-történelmi logika mentén határolódtak le. Azon lehet vitatkozni, hogy ezek a kezdeményezések mennyiben hoznak újat a korábbi, unión belüli, s azon kívüli nagytérségi együttműködésekhez képest, s ezt meg is teszik sokan 
(Stocchiero 2010). Ma már ezekkel a szerveződésekkel kapcsolatban közismertté vált egy hasonlat: „old wine in a new bottle”. Tehát az elemzők nem látnak sok újdonságot a korábbi, mérsékelt sikert elérő kezdeményezésekkel szemben.

A nagytérségek müködésének eredményét, sikerét nagymértékben befolyásolják a belső regionális jellemzőik. Dangerfield (2010) szerint a Nordic régió eredményességének hátterében a hatékony müködési modellen kívül az áll, hogy a térség viszonylag homogén területeket ölel fel, jó irányítással, erős civil társadalommal, magas szociális és gazdasági egységességgel és erős együttmüködési hagyományokkal, valamint közös érdekeltségekkel. Mindeközben a Fekete-tengeri Gazdasági Együttmüködést inkább a heterogenitás, a gyenge, deficites államszervezetek, a gyenge civil társadalom, s az eltérö részvételi érdekeltség jellemzi, aminek következtében ez a szervezet gyengének mondható.

Ebből kiindulva a nagyrégió eredményességének egyik kulcseleme a földrajzi lehatárolása, a lehatárolt térség belső jellemzői, múltbeli egysége, együttmüködési hagyományai. Mindemellett fontos megtalálni azokat a közös érdekeltségeket, amelyek valamennyi résztvevőt az aktív részvételre buzdítják, s nem utolsósorban a közös identitást, azt a szimbólumot, amelyhez valamennyi résztvevő kötődik.

A Duna esetében a szimbólum adott: a nemzeteket összekötő folyó romantikus képe mindannyiunk számára az első, ami a folyó neve hallatán megjelenik. De a közösség érzése ezen a romantikus teórián túl véget is ér. A Duna vízgyüjtője is, a folyó völgye is Európán belül egy rendkívül heterogén térség, politikai, társadalmi, kulturális, etnikai, gazdasági stb. szempontból, mindemellett számos, élő geopolitikai ellentéttel néz szembe (Hardi 2002; Rechnitzer 2009). A Duna vízgyüjtő medencéje politikai értelemben talán a legmegosztottabb ilyen egység az egész világon (2. ábra).

A vízgyüjtő területen lévő államok részesedése a térségből eltérő, ha a felszínt, a lakosságot, valamint az egyes államokban keletkezett vízmennyiséget nézzük.

Területi értelemben a legnagyobb részesedéssel Románia rendelkezik (28\%), amelyet Magyarország követ (12\%), majd Szerbia, Montenegró és Koszovó együttes részesedése következik (11\%). Az ábra még Szerbia-Montenegró létezésének időszakában készült (2006 előtt). Napjainkban Szerbia, mivel teljes területe tartozik a vízgyüjtőhöz, annak 9,6\%-át teszi ki, míg Koszovó és Montenegró közül egyik sem éri el az 1\%-os részesedést, de kis országok lévén, ez az államterületek közel felét jelenti. Kis-Jugoszlávia (Szerbia-Montenegró), illetve Szerbia szétesése miatt mára Ausztria birtokolja a harmadik legnagyobb részt a vízgyüjtőből (10\%). Mindenesetre látható, hogy az első négy állam (Románia, Magyarország, Ausztria és Szerbia) a vízgyüjtő közel 60\%-ával rendelkezik, míg a többi 16 állam osztozik a fennmaradó 40\%-on, amelyek közül 9 rendelkezik említésre méltó (1\%) feletti részesedéssel, míg 7 állam csak csekély töredékét érinti az összterületnek. 
2. ÁBRA

A Duna vízgyüjtö országai

(Countries in the Water Catchment Area of the Danube River)

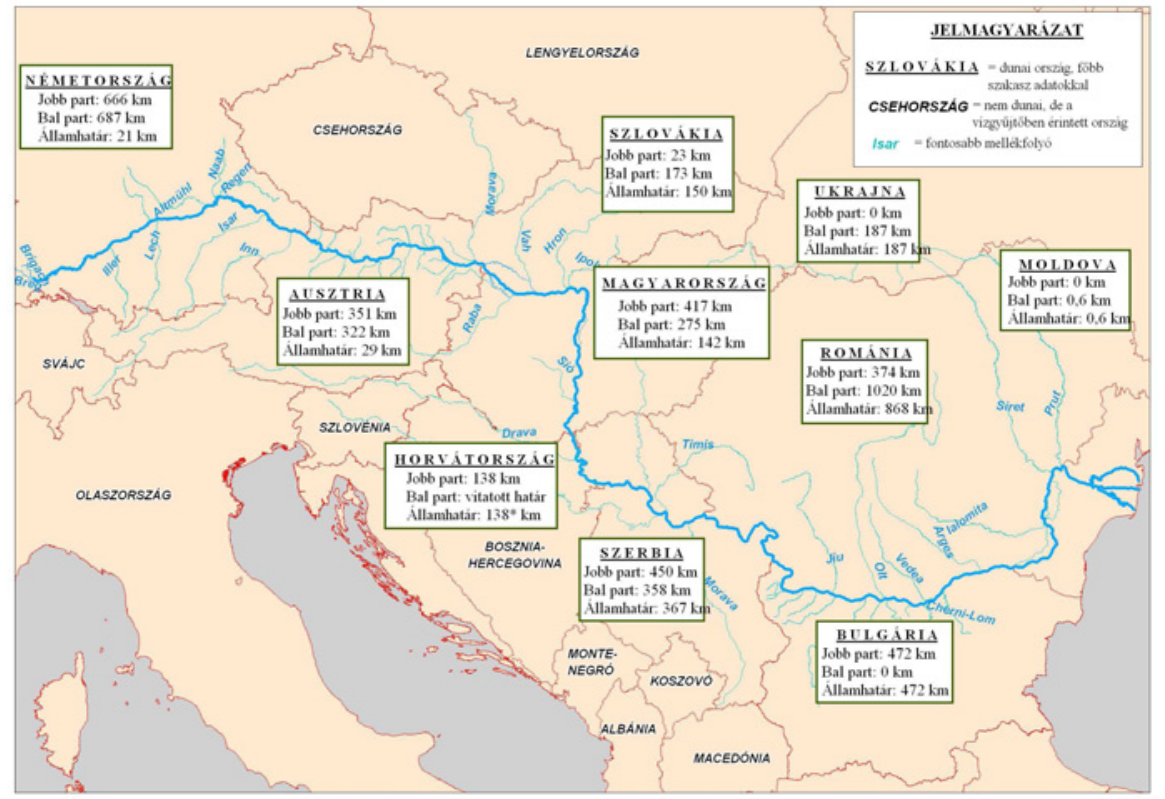

Megjegyzés: A szerb-horvát pontos határkijelölés hiányában csak hozzávetöleges adat.

Forrás: Saját szerkesztés. Kilométer adatok a Nemzetközi Duna Bizottság adatai alapján (2004).

Az együttmüködés hagyománya a térség egészére nem, legfeljebb egyes régiók, országok között mutatható ki. Tehát a makro-régiókról szóló fórum vezető profeszszorának ismérvei alapján (Dangerfield 2010) minden adott ahhoz, hogy a nagytérségben ne legyen erős az együttmüködés. Kérdés, hogy lehet-e egyáltalán egy ilyen nagy kiterjedésü vízgyüjtő területet társadalmi-gazdasági, illetve tervezési nagyrégióként meghatározni? Lehetséges-e olyan kézzelfogható eredményekkel kecsegtetni a résztvevőket, amelyek valamennyi szereplö érdekében állnak, s amelynek kedvéért együttmüködést lehet kialakítani olyan országok és területek között, amelyek között több az ellentét, mint a kapocs, s amelyek gazdasága inkább versenyben áll egymással, semmint a komparatív tényezők jellemeznék őket? Ezek jelenleg kérdések, bár kétségtelen, hogy a mögöttük meghúzódó tapasztalatok nem biztatóak.

Mégis, talán találhatók olyan elemek, amelyek elősegítik ezt a konvergenciát, s az együttmüködést szükségesnek látjuk. Közös érdekeltség nélkül az érintett államok jelenlegi és múltbeli ellentétei fontosabbak, mint az együttmüködési szándékok. Mik lehetnek ezek a közös érdekeltségek? A Duna-völgyben viszonylag egyszerü ezeket definiálni, mert a folyó, a szállítási irányok, az ökológiai, vízügyi kérdések ezeket körvonalazzák, de ide tartoznak a folyó mentén kialakult ipari és rurális térségek Dunával kapcsolatos problémái is. A nagytérségre már sokkal nehezebb megtalálni 
azokat az érdekeltségeket, amelyek valamennyi szereplő együttmüködési vágyát (a politikai szlogeneken túl) felkelthetik. Erre esélyt adhat a klímaváltozás hatásainak kezelése. Ennél a problémánál már releváns területi egység a vízgyüjtő térsége, amely így megvalósítja az érintett országok problémaközösségét.

Témánkat tehát két megközelítésben kell párhuzamosan tárgyalni, két problémára kell választ adni:

1) A jelenlegi, a Duna stratégia számára lehatárolt terület alkalmas-e arra, hogy széles körü, fejlesztési célú együttmüködést valósítsanak meg a részt vevő szereplők? Illetve: ez a területi lehatárolás milyen típusú együttmüködés számára kínál alkalmas földrajzi keretet?

2) Másrészt: egy intenzív gazdasági-fejlesztési együttműködés számára milyen földrajzi teret tudnánk kijelölni, ahol a megoldandó közös problémák felülírják a geopolitikai, etnikai ellentéteket?

Mindenképpen értenünk kell, hogy jelenleg, a Duna térség szempontjából egy olyan történelmi pillanat jött el, amikor a vízgyüjtó államainak döntő része azonos politikai, gazdasági, ideológiai térhez tartozik, s ez talán elősegítheti a Dunának, mint fejlesztési forrásnak a közös hasznosítását. Európa nagy, fejlődési tengelyei jelenleg a térség nyugati és középső részét érintik, ott alakulnak ki azok a térszerkezeti elemek, amelyek a térséget a kontinens fejlett részéhez kapcsolják (Rechnitzer 1998). Azonban, ha áttekintjük azokat az ábrákat, amelyek Európa gazdasági térszerkezeti rendszerét felvázolták az elmúlt két évtizedben (Szabó 2009), csak Van der Meer „Vörös polipja” nyújtja ki egyik csápját a Duna folyó mentén, nagyjából Belgrádig (Van der Meer 1998).

A Duna az utóbbi két évszázadban valóban rendelkezett politikai és gazdasági térszervező erővel. Viszont tekintettel kell lenni arra, hogy egyetlen más európai folyóhoz és vízgyüjtỏ területhez sem kapcsolódik annyi eltérő politikai, geopolitikai koncepció, eszmei tartalom, mint a Dunához (Hajdú 2002). A jövő és a tervezés szempontjából komoly kérdés, hogy a Duna térséget tekinthetjük-e egy potenciális gazdasági fejlődési egységnek, vagy csak földrajzi egységként kezelhetjük?

\section{A Duna térség egység?}

A Duna stratégia megalkotásának egyik apropóját az adta, hogy a Duna térség államainak nagy része Románia és Bulgária 2007. évi csatlakozásával egy egységes politikai-gazdasági térhez tartozik. A horvát csatlakozási folyamat elörehaladásával ez a helyzet rövidtávon tovább javul, s Szerbia is uniós elkötelezettségét hangoztatja. Tehát tanúi lehetünk egy olyan történelmi pillanatnak, amikor a politikailag erősen széttagolt Duna térség államai (akár a parti, akár a vízgyüjtőn elhelyezkedő államokat nézzük) azonos ideológiai, gazdasági csoportosuláshoz tartoznak. Vélhetjük, hogy ez a helyzet új lendületet adhat a nagytérségi együttmüködéseknek, a Duna menti gazdasági fejlődésnek. 
Ki kell emelnünk ugyanakkor, hogy a látszólagos közös tér mellett a mai szuverén államok kapcsolata nem minden esetben rendezett, a Duna térség számos belső kisebb-nagyobb, szunnyadó vagy aktív geopolitikai problémával küzd. Különösen gondolni kell itt a volt jugoszláv tagállamok közötti feszültségekre, Koszovó és BoszniaHercegovina jövőjére, de nem elhanyagolható probléma Moldávia szegénysége, s szakadár területének, Transznyisztriának a sorsa sem, s Ukrajna belső feszültségei is az érintett térséget terhelik. De például gazdasági-szállítási stratégiai ellentétek léteznek Románia és Bulgária között is, nem beszélve a magyar-szlovák ellentétekről. Ezek az ellentétek felülírhatják az együttmüködési szándékot, legalábbis akadályozhatnak fejlesztéseket.

Az unió alkotta egység mellett utalnunk kell arra, hogy a térség politikai értelemben napjainkban érte el a széttagoltság legmagasabb fokát, Jugoszlávia, Csehszlovákia és a Szovjetunió szétesésével.

\section{A dunai tér civilizációs és gazdasági megosztottsága}

A mai értelemben vett Duna térség, a Duna vízgyüjtő jelentős része lényegében soha nem került egyetlen politikai alakulat keretei közé. Breu, Josef (1971) kilenc olyan birodalmat különböztet meg, amelyek területe a Duna-medence nagy részére kiterjedt. Ezek (időrendi sorrendben): a Római, a Hun, az Avar, a Frank, az Első (Dunai) Bolgár, a Német-Római Birodalom, a Magyar Királyság, az Oszmán Birodalom és Ausztria-Magyarország. Mindegyik birodalom a történelmének egy részében lefedte a vízgyüjtő jelentős részét. Kiemelkedik közülük a Római Birodalom, amely Hadrianus alatt a vízgyüjtő kb. 80\%-ának ura volt, hasonlóképpen az Avar Birodalom, majd Magyarország, amely Nagy Lajos uralkodása alatt ért el közel hasonló részesedést, valamint az Osztrák-Magyar Monarchia Bosznia annektálása után. Hozzá kell tennünk, hogy a birodalmak többsége esetében a Duna térség peremterület volt, amely elsősorban határvédelmet szolgált, így viszonylag könnyen fel is adták azt vagy annak egy részét (Római, Hun, Frank, Bolgár, Török Birodalom). Duna térségi centrummal csak az Avar Birodalom (rövid ideig), valamint a Magyar Királyság és az Osztrák-Magyar Monarchia rendelkezett.

A Római Birodalom határainak védelmére használta fel a folyót, azon csak időlegesen lépett át (Dacia 106-271), de a folyót magát sem kezelte egységként. A Római Birodalom kettészakadásával, a Bizánci Birodalom megjelenésével (3951453) a térség délkeleti része tartozott évszázadokig egységes térhez, míg a felső szakaszon a kisebb hercegségek, a Frank Birodalom, illetve a Német-Római Birodalom tartották kézben a térséget. A Római Birodalom szétszakadása térségünkben ment végbe, a folyó középső szakaszának régiója mintegy belső perifériát képezett. Bizánc és Róma befolyási övezete kialakította azokat a fö kulturális övezeteket, amelyek mind a mai napig felosztják a térséget nemcsak vallási, de kulturális, civili- 
zációs, politikai jellemzők mentén (Szücs 1983). A birodalmak gyengülése nyomán megindult migráció hozta a térségbe a szlávokat, bolgárokat, magyarokat, akik saját államokat alapítva törték meg a bizánci politikai egységet a Duna mentén. A déli területeken az Oszmán Birodalom 14-16. századi elörenyomulása olvasztotta ismét egy térbe a szétszabdalt térséget, míg ennek ellenhatásaként a Habsburg Birodalom egységesülése zajlott a Duna középső folyása mentén. Mindkét birodalom sajátos gazdasági, társadalmi, kulturális rendszert valósított meg, amelyek az etnikai különbségeket is gyakran felülírták birodalmon belül. A Török Birodalomban a vallási hovatartozásnak nagyobb volt a jelentősége, mint az etnikai hovatartozásnak (Mazower 2004; Prévélakis 2007). A 19. század elejére a német egységesítési folyamatnak és a Habsburg Birodalom erősödésének és délkeleti irányú kiterjedésének köszönhetően lényegében három nagy politikai tér osztotta fel a Duna térséget egymás között: az említett két birodalom (amely politikai értelemben át is fedte egymást a NémetRómai Birodalom, illetve a Német Vámszövetség kapcsán), valamint a Török Birodalom, amelynek északi határát tartósan a Száva és a Duna vonala jelentette. Így ekkor a birodalmi terek lényegében leképezték azt a kulturális-civilizációs hármasságot, amelyet a kora középkor megalapozott, $\mathrm{s}$ a birodalmak eltérő gazdasági-politikai és társadalmi/tulajdonlási szerkezete, irányítási filozófiája ezt a megosztottságot tovább mélyítette, s megadta a modern kor társadalmi-gazdasági jellemzőinek alapvető eltéréseit (Berend T.-Ránki 1987). Más gondolkodók a térség kettős megosztottságát hangsúlyozzák (pl. Halecky [2000], aki a nyugati civilizáció peremvidékét látja térségünkben, s gazdasági értelemben Teleki Pál is peremzónaként jellemzi, amikor Európában egy thüneni rendszer szerint kialakult piaci ellátó térség peremének fogja fel, ahol Anglia és a nyugati partvidék a központ, s térségünk a külső peremzóna, az ennek megfelelö termékekkel [Teleki 1936, 360].)

Jelen munkában egy hármas tagozódású térszerkezet mellett állunk ki, Európa keleti felét (Oroszország centrumtérségét) is mint gazdasági, kulturális és hatalmi központot tételezve fel. (Ez a térfelfogás más megvilágításba helyezi azt az elterjedt véleményt, miszerint a Duna ,rossz irányba” folyik, Európa gazdasági peremvidéke felé. Ezzel szemben a folyó alsó szakasza és torkolatvidéke Európa egyik legintenzívebb geopolitikai zónáját, térszerkezeti csomópontját jelenti, ahol nagyhatalmak, illetve gazdasági centrumok szállítási útvonalai metszik egymást, s amelynek felértékelödése napjainkban is tapasztalható [Fleischer 2008].) Így a Duna térséget is lényegében három nagy kulturális alrégióra oszthatjuk fel, amelynek hatásait tapasztalhatjuk gazdasági-társadalmi elemzéseink térmegosztásai során is. Gauthey, Jean-Marie (2008) a Duna térséget hármas tagozódásúnak látja, amely megfelel az előbb felvázolt kulturális-civilizációs felosztásnak. A térség alrégióit hercyniai, pannóniai és al-dunai szakaszokként említi (3. ábra). 


\section{3. ÁBRA}

A Duna térség alrégiói, népei

(Sub-regions and Peoples of the Danube Region)

Hercyniai

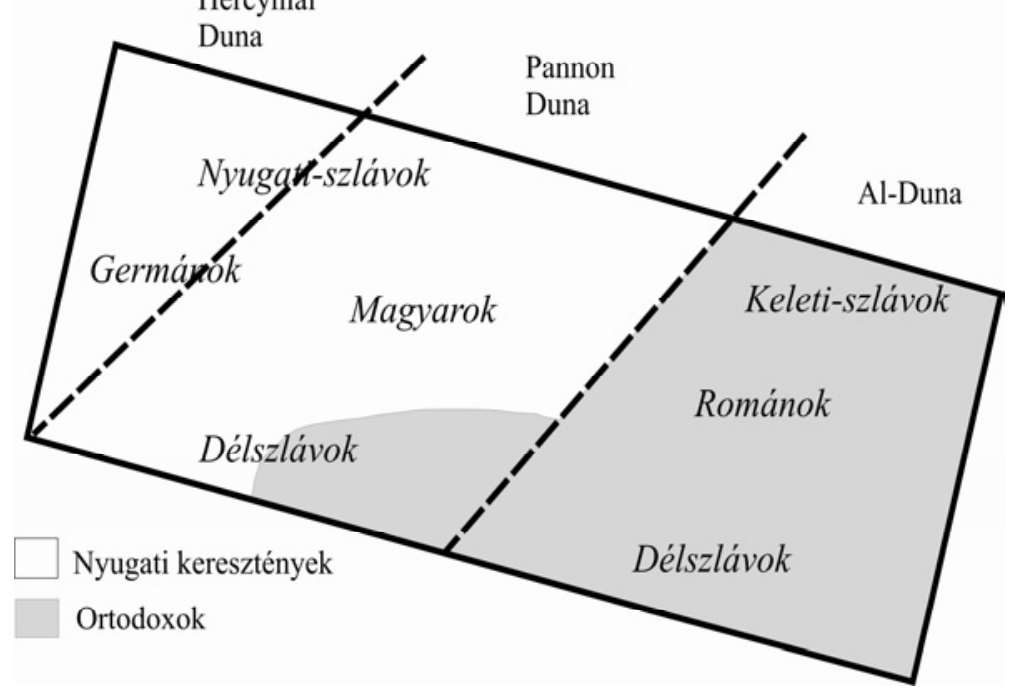

Forrás: Gauthey (2008).

A térség hármas tagozódása jól tetten érhető a gazdasági fejlettség ábrázolásakor is. Ennek érdekében készítettük el térképünket a NUTS 3 szintü területi egységek egy före jutó, folyó valutaárfolyamon mért GDP értékeiröl (4. ábra).

Ábránkból jól látható, hogy a Duna térség átvágja Európa nagy, hármas osztatú rendszerét. A korábban bemutatott kulturális-civilizációs övezetek kimutathatók a gazdasági fejlettség térképén is.

A magasabb szintủ regionális fejlettség (15 ezer euró/fő felett) Németország, Ausztria és Szlovénia keleti határainál megáll, innen keletre csak a fővárosokban tapasztalhatjuk ezt a fejlettségi szintet. Innen keletre kimutatható egy közép-európai zóna, ahol a fővárosokon kívül még találunk viszonylag fejlett régiókat, északról dél felé ez a területsáv szükül: Lengyelország, Csehország, Szlovákia, Magyarország, Horvátország alkotja. Ezeket az országokat a nyugat-keleti fejlettségi lejtő jellemzi. Európa keleti fele, az ortodox világ pedig egy újabb övezetet alkot, ahol a fôvárosok térségei emelkednek ki csupán, valamint néhány kivételes terület, pl. a kikötővárosok térsége. A fejlettség belső eltérései is átalakulnak: Ukrajnában pl. a fejlettségi lejtő keletről nyugat felé tart. 


\section{4. ÁBRA}

NUTS 3 szintü területi egységek egy före jutó bruttó hazai terméke folyó árfolyamon számolva, 2007, euró/fö (A Duna térség kiemelve)

(Gross Domestic Product per Capita in the NUTS 3 Spatial Units at Current Currency Exchange Rates, 2007, €/Capita [Danube Region Emphasised in the Map])

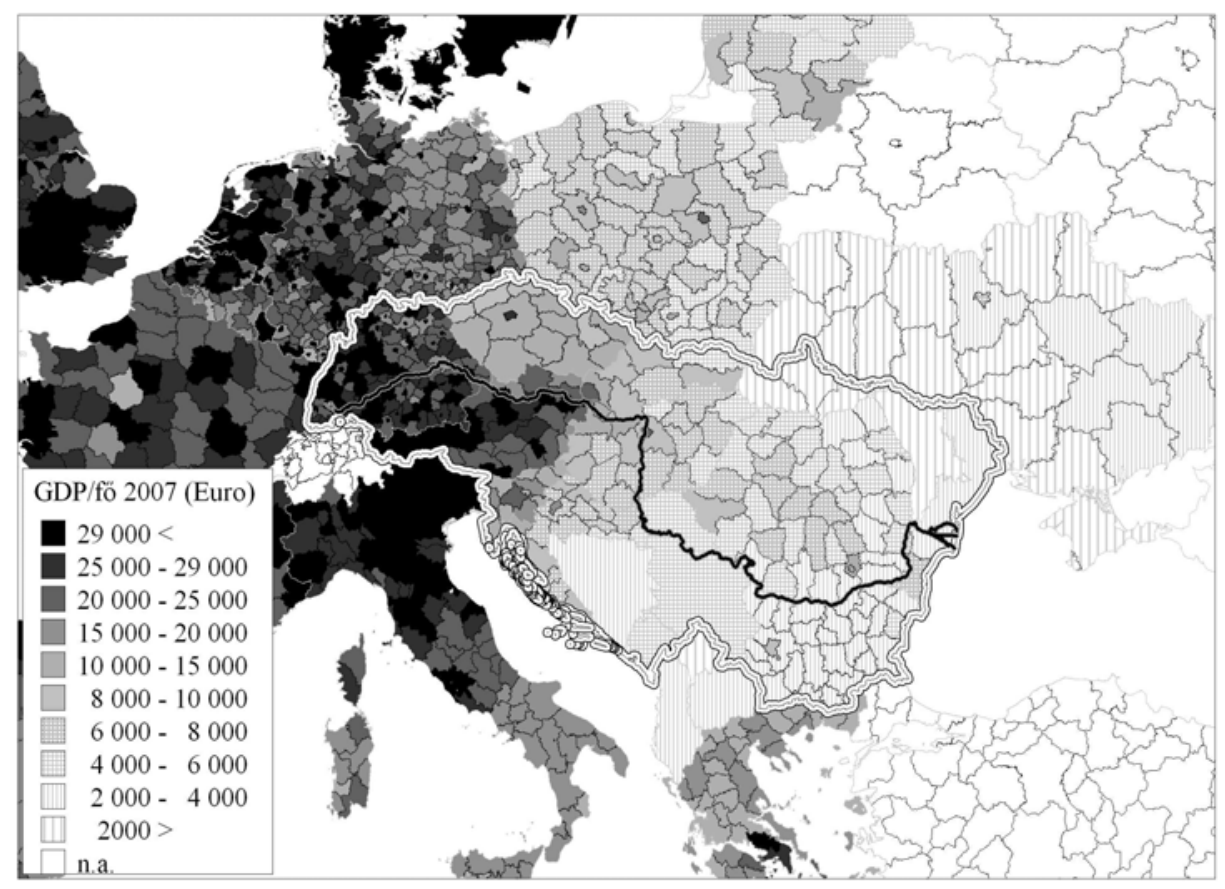

Forrás: Eurostat és nemzeti statisztikai hivatalok adatai alapján saját szerkesztés.

Napjaink sajátossága, hogy a szegényebb térségek növekedési üteme gyorsabb. Erre nézve sajnos nem teljes körüen tudtunk adatokat beszerezni, ezért csak egy szűkebb területre tudtuk elvégezni a számítást és az ábrázolást (5. ábra). Ha csak a volt szocialista országokat nézzük, akkor sajnos azt tapasztalhatjuk, hogy a lejtő „,befelé” mutat, vagyis a magyar megyék növekedése elmarad a cseh, szlovák és román értékektől. 


\section{5. ÁBRA}

A Duna térség NUTS 3 régióinak fejlettségi szintje 2007-ben GDP/fö euróban, s növekedése 2001 és 2007 között (\%)

(Gross Domestic Product per Capita in the NUTS 3 Spatial Units at Current

Currency Exchange Rates, 2007, €/Capita and the GDP Growth between 2001 and 2007)

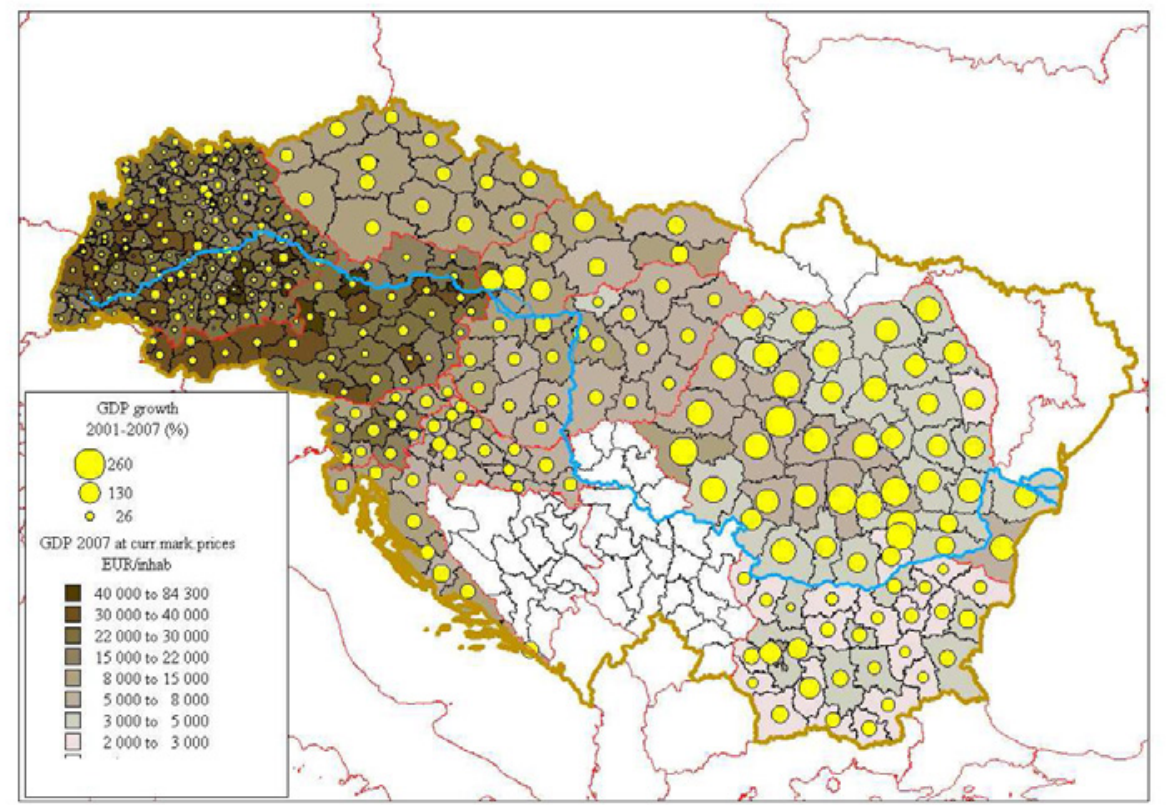

Forrás: Eurostat és nemzeti statisztikai hivatalok adatai alapján saját szerkesztés.

\section{Az egységes dunaiság alapjai}

Az érdekelt nagyhatalmak 19. századi gazdasági fejlődése teremtette meg a dunaiság közös eszményét, aminek alapja a szabad hajózás létrejötte volt. A Duna, mint vízi út a német és osztrák hatalom gazdasági fejlődésének egyik motorjává vált (igaz, viszonylag gyorsan átvette a szerepét a vasút). A történelemben elöször Ausztria, illetve az Osztrák-Magyar Monarchia kezelte a Duna térséget egy integrált gazdasági térként (Inotai 2006), gondoljunk csak az al-dunai tervekre, fejlesztésekre, beruházásokra, a kereskedelmi hajózás megszervezésére, különösen Széchenyi Dunával kapcsolatos tevékenységére (Gulyás 2009)!

Korábban a hajózás lokális jelentőségű volt, a különböző vámok és feudális érdekeltségek miatt a hosszú távú forgalom lehetősége csekély volt. A felső szakaszon uralkodó feudális felfogás értelmében a folyamhajózás a hübéri birtokból származó jog volt. Az alsó szakaszon a szabad hajózást nehéz volt biztosítani, a Török Biro- 
dalom lezárta a Fekete-tenger kijáratát jelentő Boszporuszt, s az orosz-török háborúk is érzékenyen érintették a kereskedelmet. A 19. század elején Oroszország megszerezte a Delta-vidéken a Szulinai-, majd a Szent György-ágat is (1823), így a torkolat, illetve a hajózó út elhanyagolásával bénította a hajózást, nyilván Odessza kereskedelmi helyzetének javítása érdekében. A szabad hajózás igénye számos békekötésnél, kongresszuson felmerült, de a valódi szabad hajózást - az európai folyók közül utolsóként - csak a krími háború után, 1856-ban tartott párizsi konferencia érte el, először teremtve meg a vízi út egységét (A Pallas Nagy Lexikona 1893). A német és osztrák érdekek a Duna bekapcsolását szorgalmazták az európai vízi út rendszerbe, ezzel a gazdasági fejlődési központok számára az olcsó vízi szállítási lehetőséget kívánták egységesen megteremteni. A tervezett csatornák közül a legtöbb csak terv maradt. A Duna-Majna csatorna (Lajos-csatorna) el is készült a 18. század végén, de kis méretei miatt az átmenő forgalomra nem volt alkalmas. A Duna-Moldva csatorna Linz és Ceské Budejovice összekötésére, a Duna-Odera (tovább a Visztula és a Dnyeszter, valamint az Elba összekötésével) csatornát a sziléziai szén szállítására tervezték, elsősorban Bécs irányába, a Duna-Vág csatorna Pozsonyt szolgálta volna ki, a Duna-Száva csatorna a vízi út megrövidítését szolgálta volna Bosznia, Dél-Ausztria, illetve Fiume irányába, a Károlyvárosig terjedő hajóutat 420 kilométerrel rövidítette volna meg. A Duna-Tisza csatorna megvalósult, s 1992-ben megvalósult a Duna-Rajna összekötés is, ami már a 18. század végén felmerült ötletként (sőt, a középkorban már Nagy Károly is elkezdte egy ilyen csatorna kiépíttetését). Ezek a kezdeményezések tehát a Duna felső és középső szakaszán egy egységes vízi út rendszert, ezzel egy egységes gazdasági térséget kívántak létrehozni. A megvalósítás viszont késett, a csatornaépítést törvényben a Monarchia csak 1901-ben rendelte el (1901. évi osztrák csatorna-törvény) (Révai Nagy Lexikona 1912). Ez a késés döntő lehetett, mert mire a Duna teljes hosszában a szabad hajózás megvalósulhatott, s ezzel a minden folyó hasznosíthatóságát eldöntő tengeri kereskedelem is lehetővé vált, a folyami hajózás versenytársa, a vasút indult fejlődésnek. A vasút nagyobb befektetői érdekeltséget és aktivitást vonzott, bár a századelőn világszerte ismét a csatornaépítések fellendülése volt tapasztalható, mivel a vízi szállítás még mindig jelentősen kisebb költséggel járt, mint a vasúti (azonban a hajózást bizonytalanná tevő természeti akadályokat nem sikerült legyőzni). Az első világháború, a Monarchia szétesése, ezzel az új határok keletkezése meghiúsította a csatorna terveket. Így sajnos, nem épült ki egy, a nyugat-európaihoz hasonló vízi út rendszer.

Nyilván a tengeri kijárat, a tengeri kereskedelem fontosságának felismerése vezette a Török Birodalmat is arra, hogy a Duna menti területek gazdasági lehetőségeit megpróbálja kihasználni, s igyekezzen bekapcsolódni a felvízi államok gazdasági fejlődésébe. Ezt a célt szolgálta a Duna menti bolgár területeket és Dobrudzsát magában foglaló Tuna (Duna) vilajet (Duna tartomány [A Pallas Nagy Lexikona 1893]) megszervezése, amelyet Illés Iván mint gazdasági fejlesztési mintaterületet jellemez (Illés 2007). Itt megépült a Török Birodalom első vasútvonala (1866) Várna és Rusze között, amely egy fontos gazdasági fejlődési tengelynek lett az alapja. Rusze (a vilajet központja) a bolgár területek legnagyobb városává fejlődött, 
szellemi, gazdasági központ lett. A Duna mente periférikus helyzete ugyanakkor nem javult, Rusze városán kívül gazdasági növekedési központ nem alakult ki (Fol 2001), némi fejlődés Dobrudzsában volt tapasztalható (Csernavoda-Konstanca vasút kiépítése kapcsán).

A 19. század második fele tehát az a kor, amikor a gazdasági érdekeltségeken, a hajózáson, kereskedelmen keresztül kialakult egyfajta közös „dunaiság”, dunai identitás, elsősorban a folyó menti kikötővárosokban, de a gazdasági-társadalmi fejlődés az egyes szakaszokon ezután is külön utakon járt.

A 20. század második felében a Szovjetunió nyersanyag bázisa és geopolitikai érdekei diktálták a közös dunai gazdasági fejlödést a saját érdekszférájában (Románia, Bulgária, Magyarország, Csehszlovákia), s a Duna, mint kedvező szállítási folyosó elősegítette a délkelet-európai térség ipari fejlődését. A jellemzően rurális folyó menti területek így jutottak jelentős ipari és szállítási kapacitásokhoz, amelyek egy része a rendszerváltás után tönkrement, más részük viszont logisztikai helyzetüknek köszönhetően továbbra is prosperál (pl. Galac) (Enyedi 1978; Kopralev et al. 2002; Dragoi et al. 2006; Săgeăta 2009).

A Duna menti országok politikai jellegü együttműködését, mint geopolitikai szükségszerüséget számos, egymástól homlokegyenest eltérő politikai irányzat is a zászlajára tüzte. Ezekben az esetekben a Duna csak szimbólum értékkel bírt, hiszen az aktuális szituációtól függőn terjedt ki az együttmüködés (föderáció, konföderáció) területe Lengyelországtól Albániáig, sőt Görögországig. Wesselényitől, Kossuthtól, Jászi Oszkáron, Kállay Miklóson, Szálasin, Churchillen keresztül Dimitrovig (Hanák 1985; Ádám 1987; Gyarmati 1987; Churchill 1989; Schultz 1989; Kállay 1991; Lendvay 1997) a közös elem, hogy egyik terv sem valósult meg, s mai szemmel nézve illuzórikusak is voltak.

A rendszerváltást követően számos olyan szervezet alakult, amely legalább a nevében a dunai tér megszervezésére vállalkozott általánosságban vagy egy-egy szakterületen. Így mindenképpen meg kell említenünk a Donauhansen szövetséget, a dunai városok együttmüködését. 1990-ben jött létre a Duna Menti Tartományok Munkaközössége, amelyben kilenc ország huszonhárom tartománya, megyéje müködik együtt. Fontosak a határ menti együttmüködések is. Számos eurorégió nevében jelenik meg a folyó, a dunai identitás.

Intenzívebb együttmüködési formák a szakmai szervezetek társulásai. Tizenegy ország képviselői írták alá 1994-ben, Szófiában az Együttmüködés a Duna folyó Védelméért és Fenntartható Használatáért elnevezésű egyezményt. A fenti példák azt igazolják, hogy a dunaiság eszméje nem veszett ki a huszadik század második felében sem a döntéshozók tudatából. Különböző, többé-kevésbé jól működő szervezetek, intézmények, programok jöttek létre. Ezek hasznosíthatósága annál jobb volt, minél konkrétabb közös problémához kötődtek, s ez általában a hajózás (Erdősi 2007; Fleischer 2008) és a környezetvédelem volt. 


\section{A Duna térség mint európai fejlesztési nagyrégió}

Lehetséges-e egy Dunai nagyrégió megteremtése Európán belül? Az eddig bemutatott példák alapján szkeptikusak lehetünk, legalábbis, ami a politikai összekapcsolódást jelenti. A gazdasági kényszer azonban más eset. Ebben a tekintetben viszont a rendkívül nagy különbségek hathatnak bénítóan. A stratégia kapcsán megszerveződő együttmüködő nagytérség a jelenlegi ismeretek szerint nem kap saját intézményt, forrást. A térségben nincs olyan vezetö, „húzó” gazdaság, amelynek érdeke lenne a térség gazdasági összefogása, s nem lesz intézmény sem. Mindez viszont megkérdőjelezi az intenzív gazdasági együttműködést.

A GDP adatok alapján elmondhatjuk, hogy a Duna térségben tapasztalható fejlettségi különbségek hasonló nagyságúak, mint az egész unió területén, tehát itt megtaláljuk a közösség jellemzőit „,kicsiben”. A területi átlagokat, így az átlag alatti és feletti régiók számát kimutatni azért nem tudjuk, mert négy, ráadásul szegényebb államra vonatkozóan (Bosznia-Hercegovina, Szerbia, Montenegró és Moldávia) nincs területi bontású GDP mérés. Mindenesetre így is látszik, hogy a Duna térségben a régiók lényegesen nagyobb aránya található az EU-fejlettségi átlag alatt, mint az unió egészében. Vizsgálataink szerint kb. a régiók $60 \%$-a fejletlenebb az átlagnál. Ez viszont kicsit már az újabb, nyugat-balkáni bővítés utáni szituációt vetíti elöre. Mindenesetre a fejlettségi különbségek az eddig felvázolt nagyrégiók közül a Balti térséghez hasonlatosak, de hozzá kell tennünk, hogy véleményünk szerint a szegény térségek aránya a Duna térségben lesz a legmagasabb az újonnan létrehozott nagytérségek közül.

Mint láthattuk, a Duna stratégia vonatkoztatási területeként kijelölt terület rendkívül heterogén egység, amelynek megosztottsága nem egyszerüen a modern kori gazdasági fejlődés eredménye, hanem Európa több mint kétezer éves történelmében rejlik. Éppen ezért ez a tér lehetöséget ad arra is, hogy egy új európai megbékélés kerete legyen, amelyben az eltérő kultúrák, nyelvek képesek együttmüködni egy közös érdekeltség, a fejlesztés mentén. Úgy is fogalmazhatnánk, hogy Közép- és DélkeletEurópa szén- és acélközössége lehetne, hasonlóan a nyugat-európai példához, amely ellenséges államok együttmüködését alapozta meg. Ehhez azonban konkrétan megfogalmazható közös célokra van szükség, ami nem egyszerü feladat, tekintettel a gazdasági heterogenitásra és a nagyszámú geopolitikai ellentétre és szereplőre.

Így a bevezetőben feltett első kérdésünkre azt válaszolhatjuk, hogy a jelenleg, a Duna stratégia számára lehatárolt térség egy politikai együttmüködés tere lehet, amely az unió támogatásával elösegítheti a térség egymással szemben álló kisállamainak egymásra találását, együttmüködését, amelyhez gazdasági indokok rendelhetők hozzá.

Hasonló elvek megfogalmazhatóak a többi nagytérség fejlesztésével kapcsolatban is. Érdemes azonban elgondolkodni azon, hogy ha a Duna térség történelmi, gazdasági együttműködései már léteztek, akkor azok milyen alapon alakultak ki?

A Duna térség, mint láttuk egy, a vízgyüjtő természetföldrajzi kereteit alapul vevő transznacionális tervezési keret lehet. Az együttmüködéshez szükséges közös 
érdekeltség és identitás nehezen biztosítható ezen a területi szinten, így a nagytérség szervezési elve egyértelműen politikai. Ennek megfelelően nagy súly helyeződik a részt vevő államok együttmüködési hajlandóságára, érdekeltségére.

Második, bevezetőben feltett kérdésünkkel kapcsolatban úgy tünik, a Duna-völgy az a földrajzi egység, amelyre a dunai identitás és számos közös érdekeltség utal. A folyó, mint gazdasági, fejlesztő tényező is ebben a zónában jelent/jelenik meg, tehát itt van tartalma a dunai együttmüködésnek. Nem véletlen, hogy a Duna stratégia elökészítése során, a bottom-up tervezési metodikát követve a bevont szereplök is elsősorban erre a területi kategóriára vonatkoztatták projektötleteiket.

Ismereteink birtokában leszögezhetjük, hogy a teljes Duna mentére kiterjedő együttműködés lényegében a 19. századi gazdasági növekedés kapcsán létezett, s a folyó szállítási útvonalára alapozódott, s ott és akkor valósított meg egy közös dunai identitást. A ,nagytérségi” együttmüködés nem valósult meg a nemzeti vetélkedés és a nagyhatalmi akarat következtében, s egyéb gazdasági hajtóerők hiányában. A folyó menti gazdasági együttmüködés igazából a gazdagabb államok gazdasági érdekeltségei miatt következett be. Napjainkban is látnunk kell egy ellentmondást: a „dunaiság” lényege, kimondva-kimondatlanul ma is elsősorban a közép-európai térséghez, azon belül Németország és az egykori Osztrák-Magyar Monarchia területéhez kötődik. Ugyanakkor a folyó, különösen a hajózható szakasz közel fele Romániához tartozik, s a déli szakasz vízgyüjtő területi részesedése is nagyobb, mint a középső és felső szakaszé. (Hozzá kell azonban tennünk, hogy az első világháború előtti határok szerint a történelmi Magyarország területére $953 \mathrm{~km}$ Duna szakasz esett, szinte kilométerre pontosan ekkora volt a román részesedés is [ha a Szulinai-ágon számítjuk a folyamkilométereket].)

Az egyes országok életében, gazdasági fejlődésében lényegesen nagyobb szerepet játszott a Duna a középső és felső szakaszán, mint a délin. A felső és középső szakaszokon alakultak ki azok a népességtömörülések, amelyek nemzeti központi szerepüknél, tömegüknél fogva súlyt adtak a „dunaiságnak”, hiszen Ausztria, Magyarország, Szerbia és Szlovákia nemzeti felvirágzásának nyújtottak helyszínt. Szerbia, illetve a korábbi Jugoszlávia számára is a Duna menti területek (a Vajdaság és a föváros) az ország egyik legfejlettebb részét jelentették. A mai Szerbia területén pedig egyértelmüen az ország központi fejlesztési-fejlődési tengelye a Dunával párhuzamosan határozható meg (Nagy 2007). Az alsó szakasz nemzeteinek fejlődésében nem játszott a folyó ekkora szerepet (bár Bulgária esetében a nemzeti függetlenségért vívott harc - Hristo Botev fellépése, orosz-török háborúk helyszínei kapcsolatosak voltak a folyóval). Így tehát a „dunaiság” kérdését érdemes differenciáltan kezelni. Egyáltalán, bármely történelmi-térbeli fogalom használatánál fontos tekintetbe venni annak időbeli és kulturális változatait.

A közös és a teljes térséget átfedő érdekeltség közül a legrégebbi a kontinentális, elzárt helyzetben levő, land-locked területek tengeri kijutása. Ez az akarat generálta a problémákat és az együttmüködéseket is a térségben. Ez részben kapcsolódott a Dunához, a vízi szállítás révén, de sokkal inkább a folyó mentén elhelyezkedő nagyvárosokhoz, agglomerációkhoz, s azok összeköttetéséhez. 
Ezért hosszabb távon célszerübb egy olyan stratégia megfogalmazása, amely az általános területi fejlesztés helyett jobban koncentrál ezekre a közös érdekeltségekre: az északnyugat-délkeleti és az ezt az irányt hálózattá fejlesztő észak-déli és keletnyugati összeköttetések javítására, a gazdasági növekedési központok hálózatos összeköttetésére.

Mindemellett további közös érdekeltség a vízgazdálkodás és a környezetszennyezés kérdése, amelynek összehangolását végezheti egy stratégia.

Ezért a térbeli keretekre vonatkozóan fő megállapításunk, hogy azok későbbi tisztázásához, a területi súlypontok kijelöléséhez tisztában kell lennünk a Duna stratégia távlati céljaival.

Amennyiben a stratégia céljai politikaiak maradnak, s a térség államainak kohézióját kívánják megvalósítani, úgy a széles értelemben vett területi keret integrálhatja a „problémás” területeket, segíthet eliminálni a térségen belüli ellentéteket. A gondot az jelenti, hogy ehhez a területi kerethez nem kapcsolódik a Duna, a „dunaiság”, tehát a térszervezés kiinduló alapelve. A fejlesztési források (ha a későbbiekben lesznek ilyenek) a terület nagyságához és problémáihoz képest csekélyek. Tehát ez a kategória véleményünk szerint elsősorban politikai, geopolitikai funkciókat tölthet be, kevésbé tekinthető fejlesztési eszköznek. Nyitva marad a kérdés, hogy milyen szerepmegosztás lesz ekkor az INTERREG által létrehozott transznacionális térségek és a Duna térség között?

A konkrét fejlesztések, a közös érdekeltség és a dunai identitás tere inkább a széles értelemben vett Duna-völgy. Nyilván, ma már itt sem lehet a 19. századi gazdasági fellendülés esetét, vagy akár a 20. század második felében jellemző nyersanyag-orientált Duna menti gazdaságfejlesztést alapul venni. Fontos természetesen a folyó, mint gazdasági erőforrás kihasználása, természetesen az adott szakasznak megfelelő módon, figyelembe véve az ökológiai és társadalmi fenntarthatóságot, azonban a közös fejlesztések alapját ma már a folyó mentén kialakult térstruktúrák jobb kihasználása jelentheti. Ez jelenti egyrészt a fejlett gazdasági centrumok támogatását, összekapcsolását, a folyami és tengeri kikötők hálózatának fejlesztését, de elsősorban az azokat más hálózatokba bekötő infrastruktúra-fejlesztéseket, s nem utolsósorban a folyó mentén kialakult perifériák helyzetének javítását.

Ilyen formában a Duna stratégia, akár a jelenlegi földrajzi keretek között, de a területi súlyok eltolásával továbbfejleszthető egy „folyóvölgyi tervezés” irányába, amely a folyó ökológiai rendszerét figyelembe véve, a folyó által közvetlenül kialakított, valamint a folyóval kölcsönkapcsolatban álló társadalmi-gazdasági struktúrákra, hálózatokra (csomópontokra, párhuzamos és keresztező térszerkezeti tengelyekre) koncentrál. A felvázolt két fejlesztési tér természetesen nem áll egymással szemben, azok alkalmazása kombinálható, sőt, egymást erősítve kiegészítő szerepük lehet, s kell is, hogy legyen. A Duna stratégia így szolgálhatja a térség speciális problémáinak megoldását. 


\section{Irodalom}

A Pallas Nagy Lexikona. (1893) 5. kötet. Pallas Irodalmi és Nyomdai Részvénytársaság, Budapest.

Ádám M. (1987) Egy amerikai terv Közép-Európáról. - História. 4. 16-20. o.

Berend T.I.-Ránki Gy. (1987) Európa gazdasága a 19. században, 1780-1914. Akadémiai Kiadó, Budapest.

Breu, J. (1971) Großmachtbildungen in Donauraum. - Geoforum. 6. 15-48. o.

Churchill, W.S. (1989) A második világháború. Európa Könyvkiadó, Budapest.

Dangerfield, M. (2010) Europe's Macro-Regions: Integration Through Territorial Cooperation. Paper Presented at Forum of Europe's Macro-Regions: Integration Through Territorial Cooperation. CoR 13th of April 2010.

Dragoi, I-J.-Geacu, S.-Popovici, A.-Damian, N. (2006) Romania. Space, Society, Environment. The Publishing House of the Romanian Academy, Bucharest.

Enyedi Gy. (1978) Kelet-Közép-Európa gazdaságföldrajza. Közgazdasági és Jogi Könyvkiadó, Budapest.

Erdősi F. (2007) Van-e jövője a belvízi közlekedésnek Kelet-Európában? - Tér és Társadalom. 4. 39-56. o.

Fleischer T. (2008) A távol-keleti kapcsolatok logisztikája és a Duna lehetséges szerepe. Mühelytanulmányok 78. MTA Világgazdasági Kutatóintézet, Budapest.

Fol, A. (gen.ed.) (2001) Blgaritye atlasz. The Bulgariens Atlas. Tangra, Sofia.

Gauthey, J-M. (2008) La coopération internationale sur le Danube: Géopolitique de l'intégration du fleuve au continent européen. - Balkanologie. 1-2. http://balkanologie.revues.org/index313.html. Letöltés: 2010. április 25.

Gulyás L. (2009) Reformkori kísérletek a gazdaság fejlesztésére. - Gulyás L. (szerk.) A modern magyar gazdaság története. Széchenyitől a Széchenyi-tervig. JATE Press-Szegedi Egyetemi Kiadó, Szeged. 19-29. o.

Gyarmati Gy. (1987) Magyarország és a Duna-föderációs tervek, 1945-1948. - História. 4. 20-23.o.

Hajdú Z. (2002) A politikai térstruktúrák átalakulása a Duna menti országokban. - Glatz F. (szerk.) A magyarországi Duna-völgy területfejlesztési kérdései I. Magyarország az ezredfordulón sorozat. Magyar Tudományos Akadémia, Budapest. 55-69.o.

Halecky, O. (2000) A nyugati civilizáció peremén. Osiris, Budapest.

Hanák P. (1985) Jászi Oszkár dunai patriotizmusa. Nemzet és emlékezet sorozat. Magvető Könyvkiadó, Budapest.

Hardi T. (2002) A Duna menti területek regionális különbségei, együttműködési lehetőségei. - Glatz F. (szerk.) A magyarországi Duna-völgy területfejlesztési kérdései. I. kötet. Magyarország az ezredfordulón sorozat. MTA, Budapest. 99-118.o.

Illés I. (2001) Közép- és Délkelet-Európa az ezredfordulón. Dialóg Campus Kiadó, Budapest-Pécs.

Illés, I. (2007) Transformation of the Territorial Structure in South-Eastern Europe. - Glatz, F. (ed.) The European Union, the Balkan Region and Hungary. Jahresbericht des Europa Institutes. Europa Institut - Social Research Center of HAS. 105-119. o.

Inotai, A. (2006) Der Donauraum - ein neues Wirtschaftszentrum in der erweiterten Europäischen Union? - Der Donauraum. 3-4. 225-240.o.

ICPDR (2005) Tha Danube River Basin District. ICPDR Document IC/084, 18 March 2005, Bécs.

Kállay M. (1991) Magyarország miniszterelnöke voltam. Európa Könyvkiadó, Budapest.

Kopralev, I.- Jordanova, M.-Mladenov, Ch.-Tiskov, H.-Kiradzsev, S.-Krumova, J.-Dimitrov, D.Dukova, A.-Dobrinova, R. (red.) (2002) Geografija na Blgarija. Forkom, Sofia.

Lendvay F. (1997) Közép-Európa koncepciók. Áron Kiadó, Budapest.

Mazower M. (2004) A Balkán. Európa Könyvkiadó, Budapest.

Nagy I. (szerk.) (2007) Vajdaság. Sorozatcím: A Kárpát-medence régiói 7. Dialóg Campus, PécsBudapest. Sorozatszerkesztő: Horváth Gyula.

Prévélakis, G. (2007) A Balkán. Kultúra és geopolitika. IMEDIAS Kiadó, Budapest.

Rechnitzer, J. (1998) Területi stratégiák. Dialóg Campus Kiadó, Budapest-Pécs.

Rechnitzer J. (szerk.) (2009) A Duna a magyar területfejleszzésben. MTA RKK-NFGM, Budapest-Györ.

Révai Nagy Lexikona. (1912) 6. kötet. Révai testvérek Irodalmi Intézet Részvénytársaság, Budapest; Hasonmás kiadás (1991) Szépirodalmi és Babits Könyvkiadó.

Săgeăta, R. (2009) Romania. A geopolitical outline. - Heller, W.-Arambaşa, M.N. (Hrsg.) Am östlichen Rand der Europäischen Union. Potsdamer Geogarphische Forschungen 28. Universität Potsdam, Potsdam. 45-57. o. 
Schultz, H-D. (1989) Fantasies of Mitte: Mittellage and Mitteleuropa in German geographical discussion int he 19th and 20th centuries. - Political Geography Quarterly. 4. 315-339. o.

Stocchiero, A. (2010) Macro-Regions of Europe: Old Wine in a New Bottle? Background Paper. CeSPI), Rome.

Szabó P. (2009) Európa térszerkezete különböző szemléletek tükrében. - Földrajzi Közlemények. 2. 121-134. o.

Szücs J. (1983) Vázlat Európa három történeti régiójáról. Magvető Könyvkiadó, Budapest.

Teleki P. (é.n.) A Donauraum problémája. - Európáról és Magyarországról. Athenaeum, Budapest. 152-153. o.

Teleki P. (1936) A gazdasági élet földrajzi alapjai. Centrum Kiadó, Budapest.

Nemzetközi Duna Bizottság (2004) Kilometeranzeiger der Donau. Budapest. http://www.danubecommission.org/uploads/doc/publication/KM_ANZEIGER/HTML/KILOMETERA NZEIGER.htm Letöltés: 2010. február 18

Van der Meer, L. (1998) The Red Octopus. - Blaas, W.-Matzner E. (eds.) A New Perspective for European Spatial Development Policies. Ashgate, Aldershot.

\section{THE DANUBE REGION AS A MACRO-DEVELOPMENT REGION}

\section{TAMÁS HARDI}

The macro regional alliance of countries and areas swept by the Danube is a new direction in European Union regional policy. Its development concept is under preparation which wants to determinate the common development issues in each countries and the whole area. It is an especial historical situation that the majority of countries swept by the Danube and its catchment area belong to the same common political union, to European Union.

The study aims to summarize the concepts on Danube area (political schemes, spatial issues of development plans) considering to the differences of concerned (existing today and existed earlier) countries' views. Its political importance is that a common Danube strategy should based on consensus since the determination of Danube area concerns historical issues and geopolitical concepts as well. But the too general delimitation is in danger of our area will not separate from other European macro regional/transnational concepts such as Central Europe, Southeast Europe. That is why it is important to determinate a common internal features.

Beside the examination of external borders it is necessary to analyze the internal structure of the area too. It must be aware in what case it is about common Danube area and when it is needed to handle separate its certain regions and similar problem areas. We have to analyse the internal differences of the level of social-economic development in the Danube area. We presume, this region will be one of the most problematic regions (among the planned macroregions), due to the large regional disparities.

In the basis of these observations the study aims to present alternatives what means Danube area as planning macro region, what ensures and dangers the internal cohesion of a spatial unit. In what kind of relation has got the forming and developing macro region with other macro regions, historical and geopolitical spatial categories. Exact determination of all spatial concepts, their sensitive describe could contribute to strengthen the cohesion of countries in Danube area by the preparing plan. 
$=$ 